\section{An Algorithmic Approach to the Patient with Metabolic Acidosis}

\section{Frank D Brodkey*}

Section of Pulmonary and Critical Care Medicine, School of Medicine and Public Health, University of Wisconsin, Madison, USA

\begin{abstract}
An algorithm for the evaluation of the patient with metabolic acidosis is presented and discussed, with case examples reviewed. Keywords: Anion gap; Diabetic ketoacidosis; Delta ratio; Hyperchloremia; Lactic acidosis; Metabolic acidosis
\end{abstract}

Normal acid-base status in humans involves the balance between respiratory excretion of carbon dioxide and the renal excretion of inorganic acids (predominantly $\mathrm{NH}_{4}^{+}$) as the result of protein metabolism [1,2]. The Henderson-Hasselbalch Equation measures $\mathrm{pH}$ as the calculation of degree of acidity in chemistry using $\mathrm{pKa}$, which is the negative log of an acid's dissociation constant:

$\mathrm{pH}=\mathrm{pKa}+\log 10(\mathrm{~A}-/ \mathrm{HA})$ or: (applied to human physiology) $\mathrm{pH}=6.10+\log \left(\left(\mathrm{HCO}_{3}^{-}\right) /\left(0.03 \mathrm{X} \mathrm{pCO}_{2}\right)\right.$

So that the normal human serum $\mathrm{pH}$ is 7.35-7.45 (representing a hydrogen ion concentration range of roughly $35.5-44.7 \mathrm{nEq} / \mathrm{L}$.) $[2,3]$.

The term 'acidemia' refers simply to a serum $\mathrm{pH}<7.35$; this may be due to respiratory or metabolic factors or a combination of both. The term 'metabolic acidosis' implies a pathologic condition in which a $\mathrm{pH}<7.35$ is accompanied by a lowering of the serum bicarbonate $\left(\mathrm{HCO}_{3}^{-}\right)$level.

Metabolic acidosis may be related to one or more of the following factors

1. Increased acid production e.g. lactic acidosis, ketoacidosis

2. Increased bicarbonate loss e.g. diarrhea, renal tubular acidosis

3. Reduced excretion of inorganic acids e.g. renal failure

4. Dilution of serum bicarbonate by non-balanced fluids e.g. normal saline

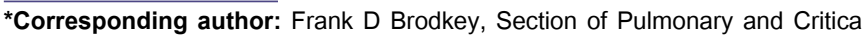
Care Medicine, School of Medicine and Public Health, University of Wisconsin, Madison, USA, Tel: +1 6087566616; E-mail: fdbrodkey@medicine.wisc.edu

Citation: Brodkey FD (2016) An Algorithmic Approach to the Patient with Metabolic Acidosis. J Emerg Med Trauma Surg Care 3: 16.

Received: December 28, 2015; Accepted: May 24, 2016; Published: May 30, 2016
The 'anion gap' is an artificial construct describing the composition and relationships between cations and anions in human serum $[4,5]$.

The most common anion gap equation is:

Anion Gap (AG) = Serum sodium minus (serum chloride plus serum bicarbonate).

Since human serum normally contains roughly $154 \mathrm{mEq} / \mathrm{L}$ of both cations and anions (to maintain electrical neutrality) and the normal $\mathrm{Na}^{+}$level is $140 \mathrm{mEq} / \mathrm{L}$, the normal level of $\mathrm{Cl}^{-}$is $108 \mathrm{mEq} / \mathrm{L}$ and the normal level of $\mathrm{HCO}_{3}$ is $26 \mathrm{mEq} / \mathrm{L}$, the concentration of unmeasured cations (e.g. calcium and magnesium) normally is approximately $(154-140)=14$ (or 10 if the contribution of potassium is ignored); whereas the concentration of unmeasured anions (e.g. phosphorus and other inorganic acids, organic acids and plasma proteins) would normally be approximately $154-(108+26)=20$.

Therefore, the anion gap may be also be summarized as:

$\mathrm{AG}=$ (unmeasured anions minus unmeasured cations); with a normal value (if potassium is ignored) of approximately 6 with a standard deviation of approximately 1.5 [6].

Because the concentration of unmeasured cations is relatively constant, even in the presence of illness, many clinicians find it useful to concentrate on the unmeasured anions in the evaluation of a patient with metabolic acidosis.

An increased anion gap, therefore, will generally imply the presence of an additional anion (acid) and will often reduce the serum bicarbonate in a 1:1 fashion. As mentioned above, the unmeasured anions in serum consist of inorganic acids, organic acids and plasma proteins (albumin); therefore an increased anion gap acidosis must be explained by the presence of one or more of the three. Examples of elevated anion gap metabolic acidosis would include lactic acidosis (organic acid), diabetic ketoacidosis (organic acid), chronic renal failure (inorganic acids) and toxic alcohol and salicylate toxicity (mostly organic acids). The acidotic patient with a normal anion gap, however, would not have the presence of additional anions in the serum and most likely be associated with loss of bicarbonate, so that acidotic patients with normal anion gaps are sometimes referred to as 'hyperchloremic'. Examples of these include acidoses related to diarrhea, renal tubular acidosis, resolution of diabetic ketoacidosis or use of carbonic anhydrase inhibitors. Of course, some patients with metabolic acidosis may have both an increased anion gap acidosis and a normal anion gap acidosis.

In some situations, the calculation of the delta ratio may be useful [7]. As noted above, most acidotic patients will have a commensurate fall in the serum bicarbonate in response to addition of unmeasured acid; but in cases of acidosis related to bicarbonate loss, for instance, the anion gap will not change as much as the serum bicarbonate. The delta ratio, therefore, is calculated as:

Delta $=($ Change in anion gap $) /($ Change in bicarbonate $)$

Metabolic acidosis related to elevated anion gap acidosis would be expected to have delta ratios of at least 1 . Diabetic Ketoacidosis is 
typified by a delta ratio of about 1 . Lactic acidosis usually has a delta ratio of 1-2 with an average of about 1.6. A delta ratio greater than two usually implies the presence of a simultaneous metabolic alkalosis.

Delta ratios $<1$ indicate a fall of $\mathrm{HCO}_{3}{ }^{-}$greater than the rise of the anion gap, indicating a contribution of a normal anion gap acidosis. Delta ratios $<0.4$ are indicative of a primary hyperchloremic nature of the metabolic acidosis.

It is important in the evaluation of a patient's metabolic acidosis as normal versus elevated anion gap to be aware of the following:

1. Unmeasured anions, as previously noted, consist of organic acids, inorganic acids and serum proteins (albumin), so that one or more of these classes must be the cause of an elevated anion gap acidosis.

2. Since albumin is a large, negatively charged molecule, conditions in which the serum albumin is lower than normal will result in a decreased concentration of unmeasured anions and therefore a lower anion gap. It is estimated that each gram/dl lowering of the serum albumin less than the normal range will reduce the measured anion gap by approximately 2.5 [8]

3. In past years, the 'normal' anion gap has been stated and popularly believed to be in the 11-15 range. With the benefit of modern ion selective electrodes, however, the anion gap in most clinical laboratories is now estimated at approximately 6 with a standard deviation of 1.5 [6]. This diminution in the calculated anion gap is mostly related to the 'rise' in the measured serum chloride related to the ion-selective electrode. The clinician should be generally aware of the normal electrolyte values in the clinician's usual laboratory.

Patients with metabolic acidosis will generally respond to the acidosis by increasing the respiratory excretion of $\mathrm{CO}_{2}$; that is, by hyperventilation, causing a lowering of the measured $\mathrm{pCO}_{2}$. This process begins within minutes and may be essentially complete with a few hours. It is clinically useful to judge the adequacy of this compensation and charts and arithmetic equations are available to help in this determination. The experienced clinician, however, can often judge this by simple review of the patient's blood gas or with the aid of a simple arithmetic equation (Winter's formula) e.g.:

Expected $\mathrm{pCO}_{2}=1.5 \mathrm{X}\left(\mathrm{HCO}_{3}{ }^{-}\right)+8$

For example, the normal respiratory compensation for a $\mathrm{HCO}_{3}$ of $16 \mathrm{mEq} / \mathrm{L}$, would lower the $\mathrm{pCO}_{2}$ to $(1.5 \times 16)+8=32$ torr, so that if this patient's $\mathrm{pCO}_{2}$ were significantly higher than 32 torr, it would represent a separate respiratory acidosis [9].

Patients may present, of course, with both metabolic and respiratory acidoses, or predominantly one or the other. Briefly, acute respiratory acidosis is partially compensated by the buffering of $\mathrm{H}_{2} \mathrm{CO}_{3}$ by intracellular proteins (such as hemoglobin) and phosphates, leading to a small increase in extracellular bicarbonate (approximately $1 \mathrm{mEq} / \mathrm{L}$ for every 10 torr increase in $\mathrm{pCO}_{2}$ ). With continuation of the elevation of $\mathrm{pCO}_{2}$ (chronic hypercapnia), the kidneys respond by retaining bicarbonate, leading to a larger increase in the serum bicarbonate of approximately $4 \mathrm{mEq} / \mathrm{L}$ for every 10 torr increase in $\mathrm{pCO}_{2}$. These formulas are of significant help in the evaluation of the acuity and significance of a complicating respiratory acidosis [10].

The patient with suspected metabolic acidosis should have blood collected, simultaneously, for routine electrolytes, $\mathrm{pH}$ and $\mathrm{pCO}_{2}$. Generally, a venous blood gas determination is sufficient for the purpose of determining the $\mathrm{pCO}_{2}$ and $\mathrm{pH}$.

\section{The following algorithm is useful in evaluating these patients}

1. Does the patient have a significant metabolic acidosis?

2. Is the respiratory compensation appropriate? Is there evidence of a separate respiratory acidosis?

3. Does the patient, predominantly, have an elevated or a normal anion gap acidosis? Is there evidence of both forms of metabolic acidosis and, if so, which is the more significant?

4. If the anion gap is elevated, what is the responsible unmeasured anion or anions among organic acids, inorganic acids and serum proteins?

Let us use this algorithm to evaluate some sample cases (in these cases common abbreviations for sodium $\left(\mathrm{Na}^{+}\right)$, Potassium $\left(\mathrm{K}^{+}\right)$, chloride $\left(\mathrm{Cl}^{-}\right)$, Bicarbonate $\left(\mathrm{HCO}_{3}{ }^{-}\right)$, urea nitrogen $(\mathrm{BUN})$ and creatinine $(\mathrm{Cr})$ are used):

\section{Case 1}

A 67 year-old man has a history of COPD and diabetic kidney disease and is admitted with worsening kidney failure, altered mental status and fluid overload. Among his labs include venous blood gases, showing $\mathrm{pO}_{2} 37$ torr, $\mathrm{pCO}_{2} 40$ torr, $\mathrm{pH} 7.22$ and $\mathrm{HCO}_{3}-16$ $\mathrm{mEq} / \mathrm{L}$. His blood chemistries include: Glucose $153 \mathrm{mg} / \mathrm{dl}, \mathrm{Na}^{+} 130$ $\mathrm{mEq} / \mathrm{L} \mathrm{K}^{+} 5.3 \mathrm{mEq} / \mathrm{L} \mathrm{Cl}^{-} 102 \mathrm{mEq} / \mathrm{L} \mathrm{HCO}_{3}^{-} 16 \mathrm{mEq} / \mathrm{L}$ albumin $2.4 \mathrm{~g} /$ dl BUN 40 mg/dl Cr $2.8 \mathrm{mg} / \mathrm{dl}$.

Applying the algorithm, the patient definitely has a metabolic acidosis. The estimated appropriate respiratory compensation for a serum $\mathrm{HCO}_{3}$ of $16 \mathrm{mEq} / \mathrm{L}$ would be $(1.5 \mathrm{X} 16=24)+8=32$. Since this patient's measured $\mathrm{pCO}_{2}$ is actually 40 torr, this represents an additional respiratory acidosis, probably related to his COPD. The patient's anion gap is 12 , and if one were not aware that the normal anion gap in healthy individuals was approximately 6 , one might be tempted to refer to this as a normal anion gap acidosis. In addition, it is recalled that each gram/dl diminution of the serum albumin reduces the anion gap by about 2.5 , so the anion gap may be artificially reduced by about $(1.6 \times 2.5)=4$ in this case, resulting in a 'actual' anion gap of 16 .

The resultant delta ratio would then be approximately $10 / 10=1.0$ again suggestive of a elevated anion gap metabolic acidosis, as well as the patient's respiratory acidosis. The patient had a serum lactate of 1.7 $\mathrm{mEq} / \mathrm{L}$ and negative serum ketones, so the unmeasured anions much be inorganic acids or minor organic acids accumulating in renal failure. In this case, the patient's serum phosphorus was measured at 8.2 $\mathrm{mg} / \mathrm{dl}=5.33 \mathrm{mEq} / \mathrm{L}$, explaining much of the patient's elevated anion gap.

\section{Case 2}

A 37 year-old woman with a history of Type I diabetes mellitus is admitted with flu-like symptoms for a few days and non-compliance with her insulin dosing. She appears clinically dehydrated and is breathing deeply and rapidly. Her venous blood gases show $\mathrm{pO}_{2} 40$ torr $\mathrm{pCO}_{2} 11$ torr $\mathrm{pH} 6.97 \mathrm{HCO}_{3}{ }^{-} 2 \mathrm{mEq} / \mathrm{L}$. Her blood chemistries include $\mathrm{Na}^{+} 117 \mathrm{mEq} / \mathrm{L} \mathrm{K}^{+} 4.6 \mathrm{mEq} / \mathrm{L} \mathrm{Cl}^{-} 85 \mathrm{mEq} / \mathrm{L} \mathrm{HCO}_{3}^{-} 2 \mathrm{mEq} / \mathrm{L}$ Albumin $4.0 \mathrm{~g} / \mathrm{dl}$ BUN 23 mg/dl Cr $1.6 \mathrm{mg} / \mathrm{dl}$ Glucose 910 mg/dl.

Applying the algorithm, the patient clearly has a severe metabolic acidosis. Winter's formula for respiratory compensation of metabolic acidosis becomes less valid at such an extreme level, yet a $\mathrm{pCO}_{2}$ of 11 torr certainly is near the maximum ability of respiratory 
compensation. The patient's anion gap is 30 , so this is, of course an elevated anion gap acidosis. The delta ratio is approximately $24 / 24=1.0$, which is typical for diabetic ketoacidosis.

In diabetic ketoacidosis (DKA), the lack of insulin forces the body to metabolize lipids and amino acids for energy [11]. Free fatty acids are formed and these are further metabolized to ketones, which are strong organic acids. The major acidic ketones are beta-hydroxybutyrate $(\mathrm{B}-\mathrm{OH})$ and acetoacetate and the ratio between the two varies according with the degree of acidosis $\left(\mathrm{NADH} / \mathrm{NAD}^{+}\right)$. In the usual patient with DKA, most of the acidic ketone is $\mathrm{B}-\mathrm{OH}$, but the amount of acetoacetate may also be significant. This is important, because acetoacetate is not measured in most clinical laboratory evaluation of ketones. Acetone is electrically without charge and would not enter into our formulas.

In addition, patients with DKA may also, as in this case, have a degree of lactic acidosis. This may relate to dehydration and poor tissue perfusion, but also to altered glucose metabolism.

The patient's serum ketones were measured at $12.11 \mathrm{mEq} / \mathrm{L}$ and her serum lactate was $3.1 \mathrm{mEq} / \mathrm{L}$, which adds up to 15.2 out of the patient's excess anion gap of 24. Since the patient has some degree of renal dysfunction, there may be a contribution of inorganic acids, such as sulfates and phosphate, as well as acetoacetate, noted above.

The patient was treated for her DKA with an insulin infusion and saline hydration. A day later, she was clinically much better. Her labs, then, included: Venous gases: $\mathrm{pO}_{2} 41$ torr $\mathrm{pCO}_{2} 33$ torr $\mathrm{HCO}_{3}{ }^{-} 16$

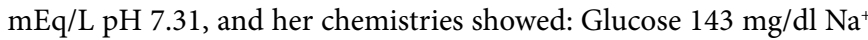
$132 \mathrm{mEq} / \mathrm{L} \mathrm{Cl}^{-} 108 \mathrm{mEq} / \mathrm{L} \mathrm{CO}_{2}$.

Applying the algorithm, the patient continues to have a significant metabolic acidosis, though, of course, improved. The respiratory compensation for a serum $\mathrm{HCO}_{3}$ of $16 \mathrm{mEq} / \mathrm{L}$ would be estimated at $(1.5 \mathrm{X} 16=24)+8=32$, so that would be appropriate. The anion gap is 8 with would be considered at the upper edge of normal for the anion gap and the delta ratio is approximately: $2 / 10=0.2$.

Therefore, the patient, primarily, has a non-anion gap or hyperchloremic acidosis. This is common on recovery from diabetic ketoacidosis because ketones, which are strong organic acids, are excreted into the urine with a cation to maintain electrical neutrality. This is sometime referred to as 'loss of potential bicarbonate' Therefore, $\mathrm{HCO}_{3}^{-}$may be replaced by $\mathrm{Cl}^{-}$in the patient's blood, especially, as in this case, when the patient has already received large volumes of chloride containing IV solutions for resuscitation. This results in replacement of a severe elevated anion-gap acidosis with a less severe non-anion gap acidosis.

\section{Case 3}

A 77 year-old man was seen in the ED because of mental confusion and gait difficulties, present over the last few days. The patient had a history of multiple intestinal resections for bowel obstructions and had been left with a short gut, for which he had previously been on total parenteral nutrition for a few months. The total parenteral nutrition had eventually been weaned and discontinued, so that he was able to tolerate a normal diet with mild diarrhea. He was on no medications, though he had recently finished a course of clindamycin for a dental infection.
His laboratory work included a set of venous blood gases, showing $\mathrm{pO}_{2} 37$ torr $\mathrm{pCO}_{2} 30$ torr $\mathrm{pH} 7.31$ and $\mathrm{HCO}_{3} 15 \mathrm{mEq} / \mathrm{L}$. Blood chemistries showed a Na${ }^{+} 144 \mathrm{mEq} / \mathrm{L} \mathrm{K}^{+} 4.1 \mathrm{mEq} / \mathrm{L} \mathrm{Cl}^{-} 102 \mathrm{mEq} / \mathrm{L} \mathrm{HCO}_{3}$ $15 \mathrm{mEq} / \mathrm{L}$ BUN $12 \mathrm{mg} / \mathrm{dl}$ Cr $1.0 \mathrm{mg} / \mathrm{dl}$ Glucose $132 \mathrm{mg} / \mathrm{dl}$ Phosphorus $2.6 \mathrm{mg} / \mathrm{dl}(1.69 \mathrm{mEq} / \mathrm{L})$ Albumin $3.9 \mathrm{~g} / \mathrm{dl}$, ketone $0.51 \mathrm{mEq} / \mathrm{L}$ and serum lactate $1.12 \mathrm{mEq} / \mathrm{L}$. Acetaminophen and salicylate levels and blood ethanol levels were zero and his serum osmolality was 298 $\mathrm{mmole} / \mathrm{kg}$.

Applying the algorithm, the patient is significantly acidotic. The predicted $\mathrm{pCO}_{2}$ from respiratory compensation would be approximately $(1.5 \mathrm{X} 15=22.5)+8=30.5$ torr, so that is appropriate. The anion gap is calculated at 17 , which is significantly elevated.

What is (are) the unmeasured anion? Since the serum albumin is normal, the unmeasured anion(s) must be inorganic or organic acids. The patient's renal functions are normal, as is the phosphorus level, so it is unlikely that we are dealing with an inorganic acidosis. Therefore, the unmeasured anion is likely to be a truly unmeasured organic acid, especially with the serum lactate and ketone levels low. That is, the patient most likely suffers from an undiagnosed toxic organic acid; most likely a toxic substance metabolized to an organic acid or acids.

Examples of this situation would include intoxication with ethylene glycol (metabolized to oxalic acid and glycolic acid) or methanol (metabolized to formic acid) but these are probably ruled out by the patient's normal serum osmolality.

The patient's serum was sent to a reference laboratory, where his D-lactate level was found to be $7.9 \mathrm{mEq} / \mathrm{L}$. The typical serum lactate assay performed in clinical laboratories uses the L-lactate dehydrogenase enzyme and generally measures only L-Lactate, which was normal in this case. D-Lactic acidosis is a syndrome of elevated anion-gap acidosis and neurologic debility occurring in patients with a short gut, usually after jejunal-ileal bypass surgery [12]. In this condition, ingested carbohydrates and metabolized by colonic lactobacilli to D-Lactate. In this case, the patient's recent antibiotic exposure may have led to overgrowth of colonic bacteria. This case illustrates that organic molecules occur as stereoisomers and may differ in their testing as well as clinical importance.

\section{Case 4}

A 78 year-old white man is recently diagnosed with multiple myeloma. His laboratory work includes venous blood gases: $\mathrm{pO}_{2} 39$ torr $\mathrm{pCO}_{2} 38$ torr $\mathrm{pH} 7.29$ and $\mathrm{HCO}_{3} 18 \mathrm{mEq} / \mathrm{L}$. Among the rest of his labs are: $\mathrm{Na}^{+} 129 \mathrm{mEq} / \mathrm{L} \mathrm{K}^{+} 5.0 \mathrm{mEq} / \mathrm{L} \mathrm{Cl}{ }^{-} 100 \mathrm{mEq} / \mathrm{L} \mathrm{HCO}_{3}{ }^{-} 18 \mathrm{mEq} / \mathrm{L}$, BUN $32 \mathrm{mg} / \mathrm{dl} \mathrm{Cr} 2.9 \mathrm{mg} / \mathrm{dl}$ Total protein $12.0 \mathrm{~g} / \mathrm{dl}$ albumin $2.2 \mathrm{~g} /$ dl Calcium $12.4 \mathrm{mg} / \mathrm{dl}(6.2 \mathrm{mEq} / \mathrm{L})$, and Phosphorus $6.2 \mathrm{mg} / \mathrm{dl}(4.0$ $\mathrm{mEq} / \mathrm{L})$.

Applying the algorithm to this case, the patient certainly has a metabolic acidosis and since the predicted $\mathrm{pCO}_{2}$ with a serum $\mathrm{HCO}_{3}$ of $18 \mathrm{mEq} / \mathrm{L}$ would be approximately $(1.5 \mathrm{X} \mathrm{18})+8=32$ torr, there is an element of respiratory acidosis, as well. If one were unaware that the 'normal' anion gap is approximately 6, one might refer to this metabolic acidosis as a non-anion gap metabolic acidosis; but the acid-base picture is much more complicated.

First, the serum albumin is about 2 grams lower than normal, which would lower the calculated anion gap by about 5 . In addition, the elevated serum calcium level would also lower the anion gap by about 1 . This would 'increase' the anion gap in this case to $11+5+1=$ about 17 , but that is not the end of the story.

As mentioned, in most cases, the globulin fraction of serum proteins does not exhibit a significant ionic charge and therefore is 
usually ignored in our calculations of the anion gap (compared to the negatively charged albumin). In malignant and benign paraproteinemias, however, there may be a significant positive charge from the $\operatorname{IgG}$ heavy chain and a lesser negative charge from the IgA heavy chain $[8,13,14]$. The amount of the positive charge associated with the IgG heavy chain is approximately $0.8 \mathrm{mEq}$ per gram.

Since this patient's IgG level was $6.1 \mathrm{grams} / \mathrm{dl}$, the anion gap would be further reduced by 6.1 X $0.8=4.9$. Therefore, the patients' 'effective anion gap' would be approximately $17+5=22$, demonstrating a significant anion gap metabolic acidosis.

The presence of significant paraproteinemia, such as malignant or benign hematologic dyscrasia may, as noted, lead to an increased level of unmeasured cations and, thereby, a lower or even negative anion gap $[13,14]$. The presence of a very low or negative anion gap in an otherwise healthy individual, however, is usually of no clinical concern and need not lead to a search for hematologic diseases in most patients [8].

\section{Conclusion}

The understanding of human acid-base pathophysiology and use of a simple algorithm are of great help in the evaluation of the acidotic patient.

\section{References}

1. Curthoys NP, Moe OW (2014) Proximal tubule function and response to acidosis. Clin J Am Soc Nephrol 9: 1627-1638.

2. Rose BD, Post TW (2001) Clinical Physiology of Acid-Base and Electrolyte Disorders. In: Rose BD, Post TW (eds). Physiology of Acid-Base Disorders, (5thedn), McGraw-Hill, New York, USA.
3. http://www.faa.gov/data_research/research/med_humanfacs/oamtechreports/1960s/media/am68-23.pdf

4. Emmett M, Narins RG (1977) Clinical use of the anion gap. Medicine (Baltimore) 56: 38-54.

5. http://www.hcplive.com/contributor/frank-brodkey/2014/09/tales-of-the-anion-gap-part-i

6. Winter SD, Pearson JR, Gabow PA, Schultz AL, Lepoff RB (1990) The fall of the serum anion gap. Arch Intern Med 150: 311-313.

7. Wrenn K (1990) The delta (delta) gap: an approach to mixed acid-base disorders. Ann Emerg Med 19: 1310-1313.

8. Kraut JA, Madias NE (2007) Serum anion gap: its uses and limitations in clinical medicine. Clin J Am Soc Nephrol 2: 162-174.

9. Wilcox (2009) Handbook of Nephrology and Hypertension (6thedn).CBS Publishers \& Distributors, new Delhi, India.

10. Martinu T, Menzies D, Dial S (2003) Re-evaluation of acid-base prediction rules in patients with chronic respiratory acidosis. Can Respir J 10: 311-315.

11. http://www.anaesthesiamcq.com/AcidBaseBook/ab8_2.php

12. Kowlgi NG, Chabbra L (2015) D-Lactic Acidosis: An Underrecognized Complication of Short Bowel Syndrome. Gastroenterol Res Pract 2015: 476215.

13. Mansoor S, Siddiqui I, Adil S, Nabi Kakepoto G, Fatmi Z, et al. (2007) Anion gap among patients of multiple myeloma and normal individuals. Clin Biochem 40: 226-229.

14. Paladini G, Sala PG (1979) Anion gap in multiple myeloma. Acta Haematol 62: 148-152. 